\title{
Historical and Legal Aspects of the California Grand Jury System
}

\author{
Harold W. Kennedy* and James W. Briggs***
}

An adequate appreciation of the functions of a modern grand jury requires at least a superficial understanding of its historical origins. ${ }^{1}$ This is true with respect to the modern federal ${ }^{2}$ and California ${ }^{3}$ grand juries, even though the powers and duties of the latter are largely defined by statute. ${ }^{4}$

In tracing the historical origins and development of the jury of accusation, the ancestor of the grand jury, we might go as far back as Athenian history. Edwards points out that some investigators have found evidence that there was an institution in Athens performing some functions of an accusing jury, but he goes on to state that if such an institution existed, it did not survive long enough to exert an influence on the common law. ${ }^{5}$

Prior to the Norman Conquest in 1066 we find there were two institutions resembling an accusing jury, which fact has caused considerable debate as to which was the germ of the Enghish jury of accusation or presentment. The evidence of such a jury in England is found in one of the Dooms (laws) of the Anglo-Saxon King Aethelred (980-1016). This doom provided: ${ }^{\mathbf{s}}$

III. These are the laws (laga) that King Aethelred and his witan have

drawn up at Wantage for the improvement of the peace ....

3 .... And a court shall be held in every wapentake [a subdivision of the county later known as the "hundred"] and there the twelve leading

* Member, California Bar. County Counsel of the County of Los Angeles. President, National Association of County and Prosecuting Attorneys, 1955.

** Member, California Bar. Deputy County Counsel of the County of Los Angeles.

${ }^{1} \mathrm{An}$ inquiry into the functions of the early common law grand juries was deemed proper in the leading case of Hale v. Henkel, 201 U.S. 43 (1906) in determining that a federal grand jury had power to initiate, on its own volition, an investigation of crime. California courts have solved problems pertaining to mechanical aspects of the inodern grand jury system, such as the number of jurors required to find an accusation, by arguing directly from the results of historical studies of English grand juries. Fitts v. Superior Court, 6 Cal.2d 230, 57 P.2d 510 (1936); Coffey v. Superior Court, 2 Cal.App. 453, 83 Pac. 580 (1905).

2 Hale v. Henkel, 201 U.S. 43 (1906).

3 Fitts v. Superior Court, 6 Cal.2d 230, 57 P.2d 510 (1936); Coffey v. Superior Court, 2 Cal.App. 453, 83 Pac. 580 (1905).

4 CAC. PEN. CODE §§ 915-931. For an article pointing out the need for federal legislation more clearly defining the powers and duties of federal grand juries, see Powers of Federal Grand Juries, 4 SrAN. L. REv. 68 (1951).

5 Edwards, The Grand JuRY 1-2 (1906).

o Stephenson and Marceam, Sources of Enguish Constitutionat History 21 (1937). 
(yldestan) thegns, together with the reeve, shall come forward and swear on holy things, to be placed in their hands, that they will neither accuse any innocent man nor spare any guilty one ....

The meaning of Aethelred's law is the subject of much dispute, but it is conceivable that the law had a general application throughout England and that by the end of the tenth century local courts may have summoned a body of sworn neighbors to present crimes which lrad come to their knowledge. ${ }^{7}$

The other early institution showing signs of becoming an accusing jury is found in the Frankish kingdom, where the kings had established a summary method of ascertaining the fiscal and other rights of the crowna royal prerogative seemingly inherited from the Roman Government. ${ }^{8}$ Court officers were ordered to inquire into these royal rights by obtaining statements under oath from the neighbors. ${ }^{9}$ The Norman dukes apparently adopted similar procedures in Normandy, or at least used them for the first time when they occupied England in $1066 .{ }^{10}$ Here at least was the germ of trial by jury as it later appears in England, ${ }^{11}$ for there is no prior trace of a trial jury in Anglo-Saxon law, ${ }^{12}$ and perhaps this is the progenitor of the accusing jury as well. ${ }^{13}$

Maitland points out that there is no continuous evidence that the inquisition described in Aethelred's law was carried on to the time of the Conquest, ${ }^{14}$ whereas immediately thereafter there appears in England the practice of inquiring of a body of sworn neighbors as to royal and other rights. ${ }^{10}$ Whichever is correct-that the accusing jury finds its origin in the law of Aethelred or in the procedure emanating from the prerogative of the Frankish kings-the concept of inquiring of neighbors on their oath was not foreign to England when the practice was sanctioned by the Assize ${ }^{16}$ of Clarendon of 1166 A.D. By this assize King Henry II ordained, inter alia, that: ${ }^{17}$

For the preservation of peace and the enforcement of justice, inquiry shall be made in every county and in every hundred through twelve of the more

\footnotetext{
7 Matrland, The Constitutional History of Engrand 127 (1913).

$81 d$. at 121 .

9 Id. at 122 .

$10 \mathrm{Id}$. at 7 .

11 Ibid.

12 Id. at 120 .

13 Id. at 127.

14 Ibid.

${ }^{15} I d$. at 7.

16 "An assize (assisa) seems to mean in the first instance a sitting, a session, for example of the king and his barons; then the name is transferred to an ordinance made at such a session $\rightarrow$ we have the Assize of Clarendon, the Assize of Nortbampton, and, to look abroad, the Assizes of Jerusalem; then again it is transferred to any institution which is created by such an ordinance." Id. at 12.

${ }^{17}$ Stephenson and Marchads, Sources of English Constitutionar Historx 77 (1937).
} 
lawful men of the hundred and through four of the more lawful men of each vill, [put] on oath to tell the truth, whether in their hundred or im their vill there is any man accused or publicly known as a robber or murderer or thief, or any one who has been a receiver of robbers or murderers or thieves, since the lord king has been king. And let the justices make this investigation in their presence and the sheriffs im their presence.

Here we see a true jury of presentment-one whose function was to accuse persons of crime before the justices of the King. It was not a trial jury, for the accused person's guilt or innocence was not established by the accusation but was to be determined by a method of trial known to that day, namely, the ordeal. ${ }^{18}$ Also to be noted is that this assize imposed an additional burden upon the tithing men of the frankpledge system; it required them not only to present those who were wanted by the authorities but to take the mitiative and inform the sheriff or the King's judges of those persons who were "publicly known" or generally suspected ${ }^{19}$ of commiting the designated crimes.

The system of frankpledge requires explanation. This system has been defined as "a system of compulsory collective bail fixed for individuals, not after their arrest for crime, but as a safeguard in anticipation of it." ${ }^{20}$ Over most of England all unexcused persons were to be enrolled in a tithing, which at one time was a group of ten men headed by a tithing man. If one of the ten should commit an offense and be accused, the other mine were to produce him for trial, make good the damage caused by the guilty party and pay a fine. Twice a year at a meeting of the hundred court held by the sheriff an inquiry was made as to whether all persons required to be enrolled in a tithing were so enrolled. ${ }^{21}$

Here then is another institution which contributed to the development of an accusing jury in England. As said before, it was the Assize of Clarendon which expanded the functions of the frankpledge system to include that of presenting persons suspected of crime rather than presenting only those who had previously been accused.

To further clarify the functions of the accusing jury as it existed in 1166 there must be an explanation of the modes of trial of that day. These were four in number:

(1) Trial by battle, where the injured person would appeal to the courts and the defendant chose to clear himself of guilt by fighting the appealing person;

(2) Trial by ordeal, where the defendant was accused by mdictment, in

18 Mattrand, Tae Constitutionad History of England 128 (1913).

191 HotDSwORTH, History OF ENGLISH LAw 77 (6th ed. 1938).

20 MORRIs, THE FrankPledge Systear 1, 2 (1910), quoted in 1 Holdsworth, supra note 19 at 13.

21 Id. at 13. 
which case it was considered the judgment of God that he was innocent if he successfully passed the ordeal;

(3) Trial by oaths or compurgation, where, depending upon the nature of the offense, the defendant was permitted to clear himself of guilt by his own oath or by the oaths of a specified number of oath-helpers; and

(4) Trial by jury, though not yet used in criminal cases, in which a certain number of men answer under oath the questions propounded to them. ${ }^{22}$

This primitive trial by jury bore little resemblance to the modern jury trial - there was no evidence submitted nor examination or cross-examination of witnesses - the jurors being expected to know of their own knowledge the answers to the questions. ${ }^{23}$ The evidentiary procedure being then unknown, it was quite natural to expect the accusing jury to present accusations based on personal knowledge. It was also inore probable that the accusing jury of 1166 would have personal knowledge of offenses committed within its jurisdiction than would the modern grand jury because at that time the accusing jurors were selected from smaller jurisdictions, namely, the subdivisions of the counties known as hundreds.

With this picture of the accusing jury of the hundred in 1166, we may now trace its developinent into the county grand jury of later, and then inore inodern, times.

The Assize of Northampton of 1176 added to the crimes enumerated in the Assize of Clarendon those of forgery, treason and arson. ${ }^{21}$ Both assizes operated to transfer jurisdiction over the offenses listed therein from the county courts to the courts held by the itinerant justices of the Crown. ${ }^{25}$ The county courts over which the sheriffs presided were thus deprived of much of their former importance. The royal courts were, however, by the Assize of Clarendon, impliedly prohibited from adjudging that trial be by compurgation for the offenses listed in the statute since trial by ordeal was the method provided. Thus compurgation as a mode of criminal trial disappeared in the royal courts, but it was continued in other courts until a much later period. ${ }^{26}$

It was late in the twelfth century when the itinerant justices traveling from county to county began to hold new commissions known as Commissions of Eyre, ${ }^{27}$ which authorized them to hear all pleas, including matters

22 MATtiand, The Construturyonal Hrstory of ENGLAND 115-124 (1913).

231 HordswORTI, HISTORY OF ENGLish LAw 333 (6th ed. 1938).

24 Id. at 71.

25 Ibid.

26 Thayer, The Older Modes of Trial, 5 HARv. L. REv. 45, 59 (1891); 1 HordsworTr, History OF ENGLISH LAW 307 (6th ed. 1938).

27 Derived from the Latin, iter, itineris, i.e., a walk, way, journey. WEBSTER's NEw INTERmational Dictionary 1320 (2d ed. 1947). 
pertaining to all phases of government. ${ }^{28}$ Summons were issued prior to the coming of the justices which resulted in large assemblages at the eyre. ${ }^{2 \theta}$ One of the principal purposes of the eyre was to obtain revenue for the King, although the avowed purpose was the impartial administration of justice. ${ }^{30}$ After the preliminary matters were disposed of, presenting juries from each hundred were chosen. The details of the mamier of choosing the presenting juries varied, but it appears that the bailiff of each hundred chose two or four electors, who in turn chose themselves and twelve others from the hundred, and from these, twelve persons were chosen to form a presenting jury from that hundred. ${ }^{31}$ To these presenting juries, the "Articles of Eyre" (consisting of questions pertaining to many phases of governinent) were read and the juries were required to give their answers by a certain day. ${ }^{32}$ The presenting juries were instructed to order the arrest of any persons suspected of crime, and if that were not possible, to give the names secretly to the justices that they might order the sheriff to take them. ${ }^{33}$

The oath to be taken at one time by the presenting jurors was that they shall "do this faithfully, that they will aggrieve no one through enmity nor show deference to any one through love, and that they will conceal those things which they have heard." 34 This appears to be the first reference to a pledge of secrecy on the part of the accusing jury, which, according to Edwards, seemed to have for its purpose the prevention of the escape of offenders. ${ }^{35}$ However, the jurors were not to keep their secrets from the justices; if the justices suspected their answers, they could examine the jurors separately or collectively to determine the reasons for their action. ${ }^{36}$

By the year 1290 the presenting jury was still coinprised of twelve members, but the oath that they then took was "that they will lawful presentment make of such chapters as shall be delivered to them in writing and in this they will not fail for any love, hatred, fear, reward, or promise, and that they will conceal the secrets, so help them God and the Saints." ${ }^{37}$ At this time the accusing jury was required, among other things, to present those who had failed in their duty to keep bridges, causeways and highways in repair; to inquire into the defects of jails and place the responsibility therefor; to deternime the responsibilities for any escapes which might have

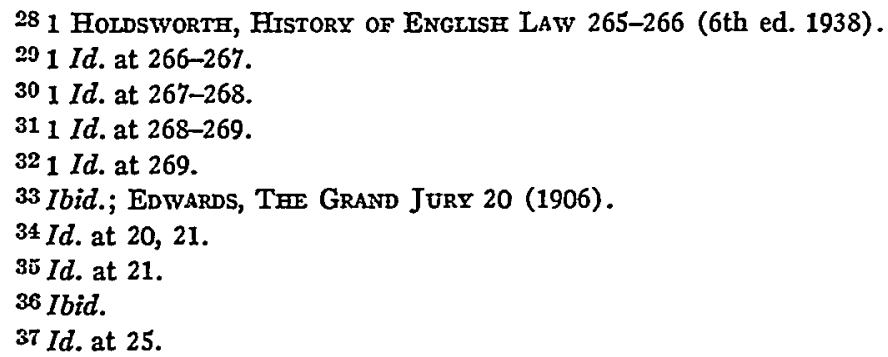


occurred; and to inquire whether the sheriff had kept in jail any who should have been brought before the justices. ${ }^{38}$

As time went on, the number and scope of the articles of eyre expanded so that they ranged over the whole field of government. We are told that "the Articles of the London Eyre of 1321 were seven times as long as the Articles of the London Eyre of 1244." 39 In the Eyre of Kent, held in 13131314 , the articles included inquiries into the neglect of police and other duties of the counties and their subdivisions; the misdoings of all officials; the usurpation or misuse of franchises; and the proprietary rights of the crown, such as escheats, wardships, and other sources of revenue. ${ }^{40}$

Thus, the main function of the eyre was to overhaul the work of the officials and courts of the county since the preceding eyre, although some criminal and civil cases were entertained. ${ }^{41}$ At the same time a procedure very similar to the eyres was being conducted in the hundreds at more frequent intervals by the sheriff, a procedure known as the sheriff's tourn. ${ }^{42}$ The sheriff's tourn also made use of presenting juries derived from the hundreds.

The eyres, by reason of their efficiency in collecting revenue and securing faithful-observance of public duties, came to be very unpopular, aud as a result of petitions came to be held not more often than every seven years, finally being abandoned altogether in the first half of the Fourteenth Century. ${ }^{43}$ With the cessation of the eyres came the first introduction of the "grand jury" of twenty-three persons to inquire of and present offenses of the entire county, rather than of the hundreds as was previously done.44 The name given to this larger body was "le graunde inquest," to distinguish the presenting jury of the county from the jury of inquest drawn from the smaller jurisdiction, the hundred. ${ }^{45}$

The grand jury was impaneled in the following manner: the sheriff summoned twenty-four persons from the county, from which twenty-three were chosen, a majority of which could decide whether to find a "true bill" or to "ignore" accusations preferred. ${ }^{40}$ The use of more than twelve persons on an accusing jury was not sanctioned by statute or prior custom; it appears that the selection of a greater number was in the beginming done at the

38 EDWARDS, THE Grand JURX 25 (1906).

391 HoldswORTH, History OF ENGLuSH LAw 269 (6th ed. 1938).

$40 \mathrm{Ibid.}$.

41 Id. at $270-271$.

42 Id. at 76.

43 Id. at $271-272$.

44 Id. at 322; see EDwards, The Grakd JURY 2 (1906), stating that the grand jury was comprised of twenty-four persons.

45 Id. at 26.

46 I HoLdsworth, History of ExGTSH LAw 322 (6th ed. 1938). 
pleasure of the sheriff. The fact that only twelve were required to find a true bill whereas unanimity was required of the trial jury points to the probability that all those over twelve were not a lawful part of the grand jury. ${ }^{47}$

In the Thirteenth and early part of the Fourteenth Centuries it seems that all or some members of the presenting jury formed part of the trial jury and that those who had indicted but failed to find the defendant guilty could be, and sometimes were, punished for contradicting themselves. ${ }^{48}$ The Crown, anxious to secure convictions, was opposed to the elimination of indictors from the trial jury but feeling against this practice forced an enactment in 1351-1352 that a juror might be challenged in a trespass or felony case if lie had been a member of the accusing jury..$^{49}$ Thus, the grand jury and the trial jury came to be more clearly dissociated, the remaining links gradually falling into disuse. It was in this period that the independence of the grand jury from the influence of the royal justices found its nrost rapid development. The justices' practice of inquiring of the grand jury the reasons for their actions when their decisions are suspected fell into disuse-perhaps because it was deemed more fruitful to inquire of the trial jury which determines guilt or innocence rather than mere suspicion and perhaps also because of an influence upon the judges of the jurors? pledge of secrecy, which contained no reservation in favor of the government. ${ }^{50}$

The independence of the grand jury from the influence of the Crown was put to severe tests in the year 1681, when the names of Stephen College and the Earl of Shaftesbury were submitted to them for indictment. These jurors, after hearing testimony of the prosecution's witnesses in open court, insisted upon the right to examine them in private. The privilege being granted and exercised, they then returned the bills "ignoranus." The grand jury in the College case, when asked by the Lord Chief Justice the reason for their verdict, rephed that they had acted according to their consciences and would stand by their finding. ${ }^{.1}$

Failure of the justices to coerce grand juries into reaching verdicts favorable to the Crown led to enactment, early in the Sixteenth Century, of a statute which provided that justices should have power to reform the panel submitted by the sheriff. ${ }^{52}$ This was to be done by striking names

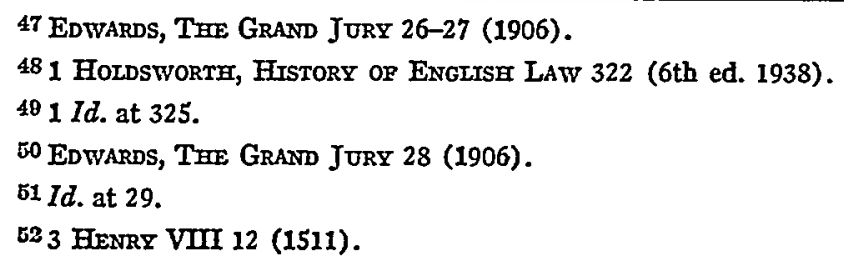


from the sheriff's list and inserting names at the discretion of the justices, and the sheriff was ordered to impanel the persons thus named. ${ }^{63}$

On one occasion the sheriffs refused to comply with the justices' order and desired to confer with their counsel. But the justices informed them that it was unnecessary inasmuch as they were all agreed that it was their duty, and the sheriffs complied. This practice was probably of short duration, however, because of more liberal policies of the Crown after the accession of William of Orange in $1688 . .^{54}$

A more recent attempt to coerce a grand jury occurred in Pennsylvania in 1783. Two justices of the supreme court ordered a printer mdicted for libel because of his criticism of that court's conduct. When the grand jury ignored the bill, the justices severely reproved them in open court and sent them back to reconsider the bill. The jury, however, refused to find an indictment. ${ }^{55}$

\section{THE GRAND JURY IN AMERICA}

The grand jury known in England at the time of the Declaration of Independence became an institution in America. Although the United States Constitution failed to guarantee a right to be proceeded against by way of presentment or indictment of a grand jury, the omission was remedied by the Fifth Amendnent. This Amendment provides that:

No person shall be held to answer for a capital, or otherwise infamous crime, unless on a presentment or indictment of a grand jury, except in cases arising in the land or naval forces or in the militia, when in actual service in time of war or public danger....

This provision applies only to criminal offenses against the United States; in Hurtado v. California ${ }^{56}$ it was held not to apply to offenses against the several states which are triable in their courts.

In the Califorma Constitution of 1879 it was provided: ${ }^{57}$

Offenses heretofore required to be prosecuted by indictment shall be prosecuted by information, after examination and commitment by a magistrate, or by indictment, with or without such examination and commitment, as may be prescribed by law ....

Several other states have adopted constitutional provisions which also

\footnotetext{
53 Edwards, The Grand Jurx 30 (1906).

54 Id. at 30-31.

$55 I d$. at 31. See also Blau v. State, 82 Miss. 514,34 So. 153 (1903).

56110 U.S. 516 (1884), holding that a prosecution for murder, after examination and commitment by a magistrate and the filing of an information by the district attorney, docs not violate due process of law even though no indictment was presented by a grand jury as was required by the common law.

57 Cat. Const. Art. I, \& 8.
} 
permit the imitiation of felony prosecutions either by indictment or information. 58

In the celebrated Hurtado case the United States Supreme Court held that the prosecution of a felony initiated by an information filed by the district attorney did not deprive the defendant of any rights under the "due process clause" of the Fourteenth Amendment to the United States Constitution, even though such a procedure did not meet the requirements of English practice.

According to a survey made by Morse in 1931, twenty-two states permit felony prosecutions to be initiated only by indictment of a grand jury; nineteen states, including California, permit felony prosecutions to be initiated either by indictment or information; the other seven states permit prosecutions by information only for certain classes of felonies, or felonies to which certain maximum penalties attach. ${ }^{59} \mathrm{It}$ appears that in the large majority of those states which permit use of both the indictment and information method of prosecuting felomes, most of such prosecutions are initiated by use of the information method. ${ }^{60}$

The survey shows that the prosecuting attorneys disagreed with the grand juries' disposition of cases in only 348 instances out of 6,453 , or 5.39 per cent of the total. ${ }^{61}$ This is some indication that there is little substance to the charge sometimes made that, because a grand juror may not be held to account for his vote, the grand jury becomes an agency without responsibility. ${ }^{62}$

\section{THE CALIFORNIA GRAND JURY}

In Califorma the grand jury is comprised of nineteen citizens of the county, sworn to inquire of public offenses committed or triable within the county. ${ }^{03}$ The jury commissioner is to furnish a list of persons qualified to serve as grand jurors, but in doing so he is at all times under the supervision and control of the judges of the superior court. ${ }^{64}$ The judges are not bound to select any names froun the jury commissioner's lists, but a majority of the judges may choose any or all of the grand jurors "from among the body of persons" in the county. ${ }^{65}$

Thus, selection of the grand jurors is largely in the control of a nuajor-

68 Morse, Survey of the Grand Jury System, 10 ORE. L. REv. 101, 121 (1931).

$69 \mathrm{Id}$. at 122 .

60 Id. at 123. This is also true in California, according to the charge of Richards, P.J., to the 1952 Los Angeles County Grand Jury 3-4 (1952).

61 Morse, Survey of the Grand Jury System, 10 Ore. L. Rev. 101, 154 (1931).

62 For such charge of "irresponsibility," see Chiperfield, The Abolition of the Grand Jury, 5 AMr. LAw 487; for a defense to the charge, see Edwards, THE Grand JuRY 40-42 (1906).

63 Car. Cone Crv. Proc. $\$ 192$.

64 Id. $\$ 204 \mathrm{~b}$.

65 Id. $\$ 204 \mathrm{~d}$. 
ity of the judges. This is significant because the survey of the grand jury system made by Morse indicates that grand jurors who are selected by a process involving the exercise of discretion and judgment on the part of competent officers are likely to act with more imitiative and independence of judgment than those who are selected by lot from tax rolls. ${ }^{80}$ Such jurors are not so apt to "rubber stamp" the actions of the prosecuting attorneys, and the juries thus formulated are not so subject to this criticism, which has often been leveled at modern grand juries. ${ }^{67}$

After the grand jury has been impaneled, each member is to be administered this oath: ${ }^{88}$

You, and each of you, will support the Constitution of the United States and of the State of California, and all laws made in pursuance thereof and in conformity therewith, will diligently imquire into, and true presentment make, of all public offenses against the people of this State, committed or triable within this county, of which you shall have or can obtain legal evidence. You will keep your own counsel, and that of your fellows and of the government, and will not, except when required in the due course of judicial proceedings, disclose the testimony of any witness examined before you, nor anything which you or any other grand juror may have said, nor the manner in which you or any other grand juror may have voted on any matter before you. You will present no person through malice, hatred or ill-will, nor leave any unpresented through fear, favor, or affection, or for any reward, or the promise or hope thereof; but in all your presentments you will present the truth, the whole truth, and nothing but the truth, according to the best of your skill and understanding, so help me God.

It is interesting to note the marked resemblance to the oaths administered to the presenting juries of early days-a resemblance which testifies to the deep-rooted origins of our present day California grand jury.

When the oaths have been administered the court must charge the grand jury as to their duties, ${ }^{69}$ then they are to "retire to a private room and inquire into the offense cognizable by thent."70

\section{Grand Jury, Court and District Attorney}

Under California law, the grand jury is expected to act in close cooperation with the court and the district attorney. Under Section 925 of the Penal Code, the grand jury is entitled at any time to ask the advice of either the court or the district attorney; the district attorney "is at all times" entitled to appear before the grand jury in order to give then infor-

\footnotetext{
66 Morse, Survey of the Grand Jury, 10 ORE. L. REv. 101, 138 (1931).

67 Powers of Federal Grand Juries, 4 Staw. L. REv. 68 (1951).

es CAI. PEN. CODE $§ 903$.

69 Id. $\$$ 905, 928.

70 Id. $\$ 906$.
} 
mation or advice pertaining to any matter within their cognizance; ${ }^{71}$ and he may question witnesses before them whenever he thinks it is necessary, except when a charge is being considered against a person connected with the district attorney's office. However, Section 925 also provides that "no person must be permitted to be present [before the grand jury] during the expression of their opinions, or giving their votes upon any matter before them." This prohibition must be regarded as applying to the district attorney as well as to other persons ${ }^{72}$ and probably grants to the grand jury the right to exclude the district attorney from its deliberations and voting ${ }^{73}$ rather than merely supplying a ground for quashing indictments. ${ }^{74}$

The California Penal Code provisions pertaining to the district attorney and the grand jury are apparently grounded on the assumption that they will closely cooperate with each other, and do not go so far as to grant the district attorney the power to exercise full control over proceedings before the grand jury. In a jurisdiction such as California, where the judges have power to exercise their discretion in selecting the grand jurors, it may be expected that such jurors will be "worthy of this high trust by their moral worth, and general respectability of character." ${ }^{75}$ Such grand jurors are not likely to become mere rubber stamps in the hands of a district attorney.

In California the grand jury is considered a judicial body ${ }^{76}$ and its members are deemed officers of the court. ${ }^{77}$ Thus a grand juror is not liable in a civil suit for determinations made by him in proceedings which are properly before the grand jury, however erroneous his decision may be and however malicious the motive which induced it. ${ }^{78}$ That the grand jury is an

71 "The district attorney or his deputies may properly appear before the grand jury, upon request of the grand jury, or otherwise, to give advice or to interrogate witnesses. Likewise, the attorney general is empowered to procure counsel to present evidence in a matter under investigation before the grand jury." McFarland v. Superior Court, 88 Cal.App.2d 153, 160, 198 P.2d 318, 322 (1948), citing CAL. PEN. CODE $§ 925$.

72 See Pcople v. Bright, 157 Cal. 663, 109 Pac. 33 (1910). The mere fact that the district attorney was at times with the grand jury in the absence of a reporter was not deemed an unauthorized presence during the deliberations of the grand jury in Stern v. Superior Court, 78 Cal.App.2d 9, 177 P.2d 308 (1947) but was considered, rather, to be within the principle that the grand jury is entitled to the advice of the district attorney.

73 See State v. McFeeley, 136 N.J.L. 102, 110-111, 54 A.2d 797, 803 (1947); Commonwealth v. Bradney, $126 \mathrm{~Pa}$. St. 199, 205, 17 Atl. 600, 601 (1889).

74 See Note, 4 A.L.R.2d 392 (1949), concerning the effect of an unauthorized person in the grand jury room on the validity of an indictment.

75 Charge of Chief Justice Shaw, Supreme Judicial Court of Massachusetts, to Grand Jury, 8 Ax. JuRIST 216, 217 (1832).

70 Greenberg v. Superior Court, 19 Cal.2d 319, 121 P.2d 713 (1942); Ex parte Sternes, 82 Cal. 245, 23 Pac. 38 (1889). Contra: Coblentz v. State, 164 Md. 558, 166 Atl. 45 (1933).

77 In re Gannon, 69 Cal. 541, 11 Pac. 240 (1886); Kelly v. Wilson, 2 Cal. Unrep. 655, 11 Pac. 244 (1886).

78 Turpen v. Booth, 56 Cal. 65, 38 Am. Rep. 48 (1880); Car. Pan. Code $\$ 927$. 
arm of the court is evidenced by the rule that a person who sends an improper letter to a grand jury pertaining to matters which it is investigating may be in contempt of court. ${ }^{79}$

The fact that the California statutes are not always explicit with respect to all matters concerning the grand jury and the fact that only nineteen members are provided for rather than the common law number of twenty-three have led to two interesting cases in California. In Coffey v. Superior Court ${ }^{80}$ the court held valid an accusation presented by a grand jury to have a chief of police removed from office for alleged misconduct, where fourteen of the nineteen members participated in returning the accusation. ${ }^{81}$ Defendant's counsel argued that all nineteen must participate to return an accusation because the Penal Code provided that twelve members could present an indictment whereas an accusation was to be presented "by the grand jury." The court answered this contention by stating that where the statute is silent reference should be made to the common law, in which the rule was that twelve members might return a true bill.

The principle of the Coffey case was carried a step further in Fitts $v$. Superior Court. ${ }^{82}$ This case was concerned with the validity of an accusation found by eleven of the nineteen members of a grand jury. The court held the accusation invalid despite the general section of the Penal Code to the effect that a majority might act on behalf of any group authorized to act as a body. The court preferred to refer to the conimon law rule that twelve members are required to return a true bill, rather than refer to the general section of the Penal Code.

Thus, although there are extensive statutory provisions governing the California grand jury, there is yet room for reference to the common law with respect to questions concerning that body.

\section{Authority to Employ}

But it is not in all cases that the California courts will look to the common law to solve problems concerning the grand jury. A typical case is one in which the grand jury desires to hire an expert to perform certain services, such as detective or auditing services.

79 Matter of Tyler, 64 Cal. 434, I Pac. 884 (1884).

802 Cal.App. 453, 83 Pac. 580 (1905).

81 As used here, the word "accusation" has a technical meaning, referring to a charge made by the grand jury accusing a public officer of willful or corrupt misconduct in office which is used to initiate an action to remove the accused person from office. Car. Govr. CoDE $\$ \S 3060-$ 3073 ; formerly CAL. PEN. CODE $\$ \S 758-771$. An "accusation," which may only result in removal from office, is thus to be distinguished from an indictment, which contemplates penal consequences. Penal Code provisions regarding "presentments" by the grand jury were repealed by Cal. Stats. 1905, c.531, p.693.

826 Cal.2d 230, 57 P.2d 510 (1936). 
The first of such cases in California, Woody v. Peairs, ${ }^{83}$ involved the legality of a claim against the county for detective services rendered to the grand jury on its request. The court did not decide the basic issue, preferring to hold that the county auditor who refused to draw his warrant for such services had been unlawfully adjudged in contempt of court because of substantial defects in the procedures followed. The court did, however, indicate that it had grave doubts as to whether the grand jury had the power to employ persons to search for evidence or subpoena witnesses other than those public officers charged with such duties.

Then, in the case of Allen v. Payne, ${ }^{84}$ the California Supreme Court held squarely that the grand jury has no power to hire a person to investigate crime and make his compensation a charge upon the county. The court rejected the argument that the California grand jury is the grand jury known to the common law, with the same power to institute its own investigations, the California Constitution having failed specifically to define the nature of the grand jury for which it provided. The court pointed out that the accepted practice in California had been to leave the detection of crime to the sheriffs and district attorneys, upon whom such duties devolved by acts of the legislature, and that those officers were the ones who had the equipment and qualified personnel to perform such work. The court also directed attention to those statutes which authorize the grand jury to employ persons qualified to do certain types of work, such as interpreters, auditors and stenographic reporters. From these instances, the court reasoned that the legislature considered the employment of persons by the grand jury as a matter to be controlled by statute, and that there would have been no necessity for such statutory authorizations if the grand jury had the inherent or imphed power to hire criminal investigators.

In the recent case of Co. of Fresno v. Roberson, $M$. \& Co. ${ }^{85}$ the Appellate Department of the Superior Court applied the reasoning in Allen v. Payne ${ }^{86}$ in holding that the grand jury was not authorized to employ an expert to examine and investigate the equipment needs of certain county offices.

In one respect this decision represents an extension of the rule in Allen v. Payne. ${ }^{87}$ Penal Code Section 928 specifically enjoined upon the grand jury in the County of Fresno case the duty of investigating and reporting upon the needs of all county offices, whereas the court in Allen v. Payne appears to have assumed that the grand jury did not itself have the power

\footnotetext{
8335 Cal.App. 553, 170 Pac. 660 (1917).

841 Cal.2d 607, 36 P.2d 614 (1934).

85124 Cal.App.2d Supp. 888, 269 P.2d 252 (1954).

86 See note 84 supra.

87 Ibid.
} 
which it delegated to an employed expert, namely, the power to "detect" crime as distinguished from the power to "investigate" crime, a distinction which is discussed below.

It is subimitted that the decision in the County of Fresno case is a sound one, ${ }^{88}$ but it, of course, remains to be seen whether it will be upheld by future decisions of the higher California courts.

\section{"Fishing Expeditions"}

As we have seen from its history the grand jury has always had the power to imitiate prosecutions based on the knowledge of one or more of the jurors. This remains true in California. Penal Code Section 922 provides:

If a member of a grand jury knows, or has reason to believe, that a public offense, triable within the county, has been committed, he must declare the same to his fellow jurors, who must thereupon investigate the same.

But this does not mean that the grand jury may in all cases initiate an investigation by reason of facts within their own knowledge. The facts nust be such as to give them reasonable grounds to believe that an offense within their cognizance has been committed. A California court, relying on the following language in the leading case of Hale v. Henkel, stated: ${ }^{80}$

[A] grand jury should not engage in "fishmg expeditions" or indiscriminate meddling with public or private affairs in which it is without jurisdiction to act or to investigate.

This doctrine may have been established in a charge of Mr. Justice Field in 1872 to a federal grand jury sitting in California. ${ }^{00} \mathrm{He}$ stated that subjects proper for inquiry should be those which are founded upon knowledge which comes to them "not by rumors and reports" but by knowledge acquired from the evidence before them or from their own observations. ${ }^{01}$

In his charge to the 1952 Los Angeles County Grand Jury, Richards, P.J., said:

You vill not institute or prosecute an investigation on the chance or speculation that some crime may be discovered. Such an investigation, based upon mere suspicion, would be odious and oppressive and is not tolerated

88 The decision is based on the fact that there is no specific authority to employ persons to perform the duty in question whereas the statutes expressly authorize employment of persons to perforn certain of the other duties of the grand jury.

80201 U.S. 43 (1906), quoted in Samish v. Superior Court, 28 Cal.App.2d 685, 688, 83 P.2d 305,306 (1938).

${ }^{80}$ Charge to Grand Jury, "Case No. 18,255," 30 Fed. Cas. 992, 2 Sawy. 667 (1872).

91 Id. at 994. Compare with the early jury of inquest in England which would present a person merely on the basis of his reputation in the neighborhood 
by law. From the time of the adoption of our constitution to the present, the accepted practice has been to leave the detection of crime in the hands of sheriffs and district attorneys.

You should not engage in "fishing expeditions," "witch hunts," or indiscriminate meddling with public or private affairs. However, when you do possess personal knowledge or are furnished with reliable information indicating that a crime has been committed by someone within the borders of this county, then it is your duty to fearlessly and fairly investigate these charges and indict the culpable party if warranted by the evidence.

Thus, although the California Grand Jury has very broad jurisdiction -it "may inquire into all public offenses committed or triable within the county" as a supervising admimistrative agency over the public officers in the county by inquiring into any of their activities it may choose; it is only to inquire "into the willful or corrupt misconduct in office" of such officers. ${ }^{93}$

\section{Duties Traceable to Early Juries of Inquest}

Several of the duties of the modern California grand jury forcibly remind us of early inquests conducted to ascertain royal rights, with special reference to the Crown's sources of revenue. These include the duty to investigate transfers and ownership of land which might escheat to the state, ${ }^{94}$ and the duty to examine the books, records and accounts of county officers and city boards of education, ${ }^{95}$ together with the right to order the district attorney to institute suit to recover any moneys which appear froin such examination to be due the county. ${ }^{96}$ Also reminiscent of the early inquests is the duty to inquire into the condition and management of the public prisons and into the case of every person imprisoned in the county jail who was not indicted. ${ }^{97}$

\section{Secrecy of Proceedings}

The right and duty of the grand jurors to conduct their investigations, deliberations and voting in secret, which were won and established in England, are substantially the same for the modern California grand jurors. ${ }^{93}$ A court can only require thein to disclose the testimony of a witness who appeared before them for the purposes of ascertaining whether it is consistent with testimony given by the witness in the court or ascertaining the

92 Car. Pen. Code $\$ 915$.

93 Id. $\$ 923$.

94 Id. $\$ 931$.

95 Id. $\$ 928$.

96 Id. $\$ 929$.

97 Id. $\$ 923$.

98 Id. $\$ 925$. 
validity of a charge that the witness is guilty of perjury. ${ }^{99}$ The grand jurors may not be questioned concerning their deliberations or voting, other than for certain perjuries. ${ }^{100}$ However, where they return an indictment or present an accusation, transcripts of the reported testimony are to be furnished the district attorney and those accused persons who are in custody. ${ }^{101}$ Also, the court may order that certain investigations be conducted in public, but this power may only be exercised with respect to matters involving misconduct of public officers which are found to affect the general welfare. ${ }^{102}$ The hard-won right of secrecy thus remains substantially unimpaired in California.

\section{CONCLUSION}

The modern California grand jury is much better understood when its historical origins are taken into consideration. Although its powers, rights and duties are largely defined by statute, problems still arise which may be and are solved by reference to the common law. There have been many attacks upon the grand jury system ${ }^{103}$-in England it was abolished in $1933^{104}$ _the most serious being that it is an outmoded institution. In our system of government, which is so jealous of the rights of suspected offenders, there is not so much need of that historical function of the grand jury of protecting the innocent from unfounded prosecutions by the government or by private prosecutors. Nevertheless, the California system of selecting grand jurors, which usually results in the selection of persons of considerable stature in the community, offers no bittle assurance to the people that the innocent will be protected while the guilty are ferreted out for the further protection of law-abiding citizens. The grand jury system helps to preserve the sense of the community in the administration of justice, a sense which has been considered important througlout the history of the accusing jury. In the words of Chief Justice Slaw: ${ }^{105}$

Coming from the various parts of the county, first designated by their townsmen, as persons well fitted by their capacity, integrity and personal worth of character, to discharge the important functions of jurors, and then for each particular service, designated by lot, without regard to sect or party, rank or condition, the Grand Jury may justly be regarded as a fair representation of the county, participating in all the interests and feelings of the people, and well acquainted with their condition and circum-

99 CaL. Pen. Code $\S 928$.

100 Id. $\$ 927$.

101 Id. $\$ 925$.

102 Id. § $925 \mathrm{a}$.

103 Morse, Survey of the Grand Jury System, 10 ORE. L. REv, 101 (1931).

10423 and $24 \mathrm{GEO}, \mathrm{V}$, c.36 (1933).

105 See note 75 supra. 
stances. They bring with them all the local knowledge and information, which are requisite to enable them to perform their important duties with efficiency, impartiality, and success.

Our study reveals that the grand jury is a component part of the California judicial system, working out of the Criminal Division of the Superior Court. This system conteniplates that the grand jury, as an adjunct of the court, will work closely with the court and the district attorney in order efficiently to discharge its duties. The system assumes the honesty and capability of its judges and district attorneys, and assumes that they, as well as the grand jury, are interested in the impartial administration of justice, granting full protection to the innocent while discovering and punishing the guilty.

The Califormia grand jury is endowed with broad powers as an inquisitorial and judicial body, but it is enjoined to exercise those powers with mature discretion. It is not to engage in "fishing expeditions," that is, initiate investigations not specifically enjomed upon it without probable cause, nor is it to attempt to act as a supervising administrative agency controlling the discretionary activities of public officers.

A grand jury which observes these limitations, while fearlessly and intelligently performing its duties, can be an effective instrument of the California judicial system. 